\title{
Codifying Cultural Heritage: Why United States Criminal Law Suddenly Treats Our Rare Materials with Respect
}

"The Cultural Heritage Guideline will, in my opinion, prove to be one of the most important of all the sentencing guidelines for the long-term benefit of our nation," said United States Attorney (now federal magistrate judge) Paul Warner. He was testifying before the United States Sentencing Commission, which was about to get serious with cultural crimes. He was also echoing what he had written in a letter to the Commission a mere three months earlier. In that letter, which fully addressed the harm caused to the American people by crimes against cultural resources, he explained that "[f]ew undertakings by the Sentencing Commission could be of greater significance to the nation."

Based on our experience in prosecuting ARPA [Archaeological Resources Protection Act] cases, and particularly in dealing with sentencing issues, we and our colleagues in the Justice Department throughout the nation became convinced that the current Sentencing Guidelines are wholly inadequate for ARPA and other cultural heritage crime offenses. These crimes cause devastating and irreparable harm to the nation's cultural heritage, yet there is no specific treatment of them in the Sentencing Guidelines. ${ }^{2}$

At the time Warner spoke those words, United States criminal law had yet to make a comprehensive effort at addressing damage done to our cultural heritage. Absent extraordinary effort, a person who stole an Anasazi pot or a letter by Abraham Lincoln could only be sentenced as if he had committed an ordinary property crime involving, for instance, fur coats, or bundles of copper wire. There was no separate treatment for the theft of unique and irreplaceable items that are so valuable to our cultural heritage. While some small efforts had been specifically made to take seriously the theft of archaeological resources, very little had yet been done con-

1. Paul Warner, Testimony before United States Sentencing Commission Public Hearing. Feb. 26, 2002.

2. Ibid. 
cerning rare books, maps, or other documents. But by February 2002, the federal government was already planning to change that state of affairs in a significant way.

\section{Sentencing Guidelines}

The United States Sentencing Commission is an agency organized under the judicial branch of the federal government. The Commission's major role is to establish sentencing policies and practices for federal courts. Created in 1984, the most important and visible product of the Commission is the Federal Sentencing Guidelines. ${ }^{3}$

The Guidelines started as an attempt to create a consistent sentencing scheme, regardless of geographical location of the crime, race or gender of the defendant, or any other factor unrelated to the crime itself. To that end, the Guidelines offered federal judges a consistent, unchanging grid. Using that grid, a particular crime could be coupled with a particular criminal's background to determine a fair sentence.

The grid has two planes. One plane represents the Offense Level-the numerical ranking of the severity of the crime a person has committed. There are 43 such levels on this plane. The other part of the grid represents the Criminal History Background of the person to be sentenced-this is the numerical ranking of that individual's prior criminal record. The Criminal History category plane has six levels. At the point where lines from those two levels meet on the grid exists a range of months from which the sentencing judge has to choose. ${ }^{4}$

For instance, a man with a substantial criminal record of theft and robbery is caught stealing cellular phones and traveling from state to state selling them. The monetary value of the crime tallies up to $\$ 20,000$. Absent any other factors either subtracting from or adding to the offense level, the total offense level would be ten. If the career criminal is assigned a level three criminal history, the two parts of the formula are complete. A level ten crime with a criminal history category of three is assigned a range of 6-12 months in prison using the Federal Sentencing Guidelines. The federal judge doing the sentencing therefore has discretion to sentence the criminal to any term of months between 6 and 12 .

This grid does two things at once. It gives federal judges latitude in sentencing, as they are able to sentence at the low or high end of the range of months recom-

3. United States Sentencing Commission, Rules of Practice and Procedure. Nov. 2001.

4. United States Sentencing Commission, Federal Sentencing Guidelines Manual (Minneapolis: Thompson-West, 2002), 1627. 
mended by the Guidelines. But it also makes sure that similar crimes committed by different people in different parts of the country are treated similarly, regardless of other factors.

What that means in practical terms is that federal sentencing is a numbers game. The job of the federal prosecutor-after a criminal has been convicted or pleaded guilty - is to make sure the offense level is large enough to match the crime. The job of the defense attorney is to lower the offense level at all costs. Since even one or two levels can amount to a substantial difference in jail time, defense attorneys focus much of their effort on seeking lower offense levels.

Without specific instructions for how cultural heritage crimes differ from other property crimes, the hands of federal judges or prosecutors were bound. Even if the people responsible for enforcing our laws were predisposed toward taking cultural crimes seriously - and placing innate value ahead of what the market dictated-there was little they could do without the right tools.

And since determining market value isn't an exact science, even the one means available for punishing theft of rare books, maps, or manuscripts had been underutilized. Following complaints from both the Departments of Justice and the Interior, amending the Guidelines was meant to rectify that failing. ${ }^{5}$

\section{The Process}

The task of amending the Sentencing Guidelines requires two separate steps that offer a natural pause in process. The Commission must ultimately send the proposed amendments, along with explanation, to Congress. ${ }^{6}$ In the case of the creation of the Cultural Heritage Resource Guideline (CHRG), this was a fairly pro-forma requirement.

But before that step can be taken, the Commission must first open the amendment up to public comment by publishing it in the Federal Register and holding a public meeting on the subject. This "notice and comment" requirement is ordinarily time consuming but effective. That was no less true in the case of this particular Guideline. It took awhile, but this process was particularly helpful in leading to the creation of a separate Guideline section instead of an amendment to an already existing Guideline.

5. United States Sentencing Commission, Public Meeting, Minutes of Nov. 14, 2001.

6. Ibid., note 3 . 
The Sentencing Commission set about the amendment process in late 2000. This original amendment was far more limited than the one that ultimately came into existence. It primarily concerned itself with adding enhancements to existing Guidelines.

To this end, the Commission in January 2001 listed a query in the Federal Register, asking for comment as "to what extent it should provide an enhancement for the destruction of, or damage to, unique or irreplaceable items of cultural heritage, archaeological, or historical significance." ment on the question of whether such enhancements could be shoehorned into the existing Guideline dealing with destruction of property in a national cemetery.

The Commission got its answer relatively quickly. Museum curators, archaeologists, federal prosecutors, and law enforcement personnel all commented on the idea of a new type of sentencing scheme in the Guidelines. ${ }^{8}$ In light of the fact that many interested parties wanted to be heard before the Commission acted, there was a delay in the promulgation of the new Guideline to give everyone a chance to present their concerns. The Commission very much wanted to accommodate the experts.

Aside from those things listed in the Federal Register, the Commission also wanted feedback on other items. Particularly, they wanted to know what ought to count as a "pattern of similar violation" and if the possession of a "destructive device" during the commission of the crime should enhance the penalty. ${ }^{9}$ After receiving comments on all of the topics they were interested in, they decided that an amendment to existing Guidelines would not be sufficient. The Commission then set about writing a new Guideline section.

Close to a year after the Commission started the process in earnest, on November 27, 2001, they had a preliminary draft of the proposed Guideline. It was again posted in the Federal Register so that interested parties (and the public) could look at it and make further comments on this early version of what would become the CHRG. In introducing the new Guideline, the chair of the Commission, Diana Murphy, explained its need:

Cultural heritage resource crimes are fundamentally different than general property crimes because, unlike other property crimes where the primary harm is pecuniary, the effect of cultural heritage resource crimes is in great part non-pecuniary in nature. Punishment of these crimes should reflect these intrinsic differences. ${ }^{10}$

7. "Notice of Proposed Amendments," Federal Register 66 (Jan. 26, 2001): 7992.

8. Minutes, note 5 .

9. Ibid.

10. "Notice of Proposed Amendments," Federal Register 66 (Nov. 27, 2001): 59330. 
Murphy went on to explain what, in practical terms, the new Guideline offered. "First, the amendment proposes a base offense level of 8, which is two levels higher than the base offense level for general property." So someone who steals one of these cultural items is immediately treated more seriously than a person who steals other, fungible items. Beyond that, "the amendment proposes a two-level enhancement if the offense involved commercial advantage or private financial gain," another two levels if it "involved a pattern of similar violations," two more levels if it "involves specially protected resources from specially protected places," and two additional levels if "a firearm was possessed or a dangerous weapon was brandished." Each of these two-level increases would add roughly six months to the sentence, depending upon the monetary value of the crime.

This was a strong and substantial Guideline, and just the sort of thing that United States Attorneys wanted to have at their disposal.

As required, after the publication of the Guideline in November, there was a public meeting held on the subject allowing interested parties to comment. On the meeting day of February 26, 2002 - the same meeting at which Paul Warner spokeJohn Fryar, an enrolled member of the Pueblo of Acoma, gave his own rationale for needing this Guideline. Speaking as an investigator for the Bureau of Indian Affairs, he described the constant battle he confronted in dealing with cultural heritage thieves; he spoke of a particularly notorious example of a man who had been stealing from tribal lands for thirty years and was convicted of twenty felonies. But due to the limitations of the existing Guidelines, the man was only sentenced to thirty-three months in jail. ${ }^{11}$

Clearly, a separate Guideline was needed. Punishment of cultural thieves under current laws was minimal, excluded consideration of the intrinsic cultural value of the items stolen, and failed to argue for damages incurred by society at large.

The testimony and public comments helped the Commission further sculpt the final product. Two months after this testimony about the new Cultural Heritage Resource Guideline, Diana Murphy, chair of the sentencing commission, sent a letter on April 3, 2002, to the two ranking chairs of the Senate Judiciary Committee, Orrin Hatch and Patrick Leahy. In it, she explained the Commission's justification for the new Guideline, writing that "offenses involving cultural heritage resources are more serious because they involve essentially irreplaceable resources and cause intangible harm to society." ${ }^{12}$ She continued:

11. John Fryar, Testimony before United States Sentencing Commission Public Hearing. Feb. 26, 2002 .

12. Diana Murphy, Letter to Patrick Leahy and Orrin Hatch, April 3, 2002. 
Upon close scrutiny, the Commission recognized that treatment of these offenses against unique and irreplaceable resources under traditional property offense guidelines would not be adequate to reflect the significance of the resources and the concomitant harm to the identity of the nation and its communities. Not only are the offenses themselves very serious and deserving of substantially more punishment, but the conduct of many of the offenders, professional looters who are well armed and dangerous to law enforcement and innocent passers-by, requires increased proportional punishment.

On May 29, 2002, the Commission listed in the Federal Register their intent to codify the new Guideline, which would be located at $\$ 2$ B1.5 in the Sentencing Guidelines. It was to go into effect in November.

With the imprimatur of Congress, the newest version of the Federal Sentencing Guidelines did go into effect in November 2002. "Theft of, Damage to, or Destruction of, Cultural Heritage Resources" was organized under $§ 2 \mathrm{~B} 1.5$ of the Guidelines. The official language justifying the change echoed much of what had been said before:

This Amendment reflects the Commission's conclusion that the existing sentencing guidelines for economic and property destruction are inadequate to punish in an appropriate and proportional way the variety of federal crimes involving the theft of, or damage to, destruction of, or illicit trafficking in, cultural heritage resources. ${ }^{13}$

To people who work with rare books, maps and documents, the language of the Cultural Heritage Resources Guideline may not initially appear to be directly related to crimes against these things; the direct language is concerned almost entirely with archaeological subjects. But while these types of thefts are not specifically written out in the Guideline, under the section "Cultural Heritage Resource" Defined, there is a reference to an existing provision of the United States Code. That provision, 18 USC $\S 668$, gives a definition of Cultural Heritage Resources that encompasses rare books, maps, and documents, describing an "object of cultural heritage" as one more than 100 years old and worth more than $\$ 5,000$. In that way, criminal sentences for thieves who steal or destroy materials from rare book and manuscript libraries or archives can be sentenced under the Guideline.

\section{Making It Work}

Promulgating a Guideline and getting prosecutors and judges to use it are two different things. To address this problem, shortly after the creation of the CHRG the 
Commission published an annotated version for training and reference purposes. The white paper explained that the Guideline could be used in conjunction with numerous already established crimes, such as Theft of Government Property, Interstate Receipt of Stolen Property, as well as the criminal provisions of the Archaeological Resources Protection Act. ${ }^{14}$

Once they knew of its existence, it didn't take long for federal prosecutors to employ the Guideline on book and document thieves. Two recent examples demonstrate the usefulness of the CHRG in prosecuting these sorts of thefts.

Howard Harner had been stealing from the National Archives for many years. ${ }^{15}$ Among the items he took were letters authored by Jefferson Davis, George Pickett, and Ulysses S. Grant. One of the letters he stole, written by General Lewis Armistead, was eventually purchased by a college in Texas for $\$ 40,000$. Harner was arrested in 2004 and sentenced for his thefts of close to 100 documents in 2005 under the two-and-a-half year old CHRG. Under this Guideline, the sentencing grid recommended a sentence of between 24 and 30 months. It is difficult to be sure "what would have happened if...," but it's certain that, without the CHRG, Harner's sentence would have been substantially lower-most likely between four and 10 months. The CHRG added fully eight levels to the Offense Level.

Later in the same year that Harner was arrested, Warren Lipka and three of his friends created a stir when they committed a strange, daylight rare-book theft. ${ }^{16}$ While two of the thieves broke into the special collections library at Transylvania University, physically subduing the special collections librarian in the process, two others waited outside in a getaway van.

The four young men were apprehended after trying to sell their wares at Christie's auction house. They were charged with numerous crimes, including two counts sentenced under $\S 2 \mathrm{~B} 1.5$. Since the other charges resulted in sentences substantially similar to those they would have received under the Cultural Heritage Resources Guideline, these counts were mooted. Nevertheless, the charges included a twolevel standard increase, two more levels for theft from a museum, another two for theft of cultural property, two additional for pecuniary gain, and two for use of a weapon in the commission of a crime. So, with Harner, the Offense Level was greatly increased.

14. United States Sentencing Commission, Annotated Cultural Heritage Guideline for Training and Reference Purposes, 2003.

15. United States v. Howard Harner, 1:05 CR 00065 -JR, Feb. 2005.

16. United States v. Warren Lipka, 5:05 CR 00039 -JBC, Dec. 2005. 
The Cultural Heritage Resources Guideline is a powerful tool that federal prosecutors now have at their disposal. Crimes involving theft of rare books, maps, or documents from libraries and archives will fall under this new Guideline. In general, this will amount to an increase of between six and eight Offense Levels per crime. At the very least, it will add up to another year in jail for the offender, but it could result in several years, depending on the monetary value involved in the crime.

Aside from this practical effect, the Cultural Heritage Resources Guideline is a substantial demonstration by the federal government that it is beginning to recognize a distinction in the nature of property crimes. Copper wire can be replaced; our cultural heritage can not.

\section{The Lawbook Exchange, Ltd.}

The Lawbook Exchange, Ltd. specializes in books, manuscripts and other items relating to law and legal history. Our publication program offers reprints of over 800 landmark works, many with new introductions, and original publications.

Collection development is one of our principal specialties, and we are proud of the assistance we have provided to many institutions worldwide over the last 25 years. We

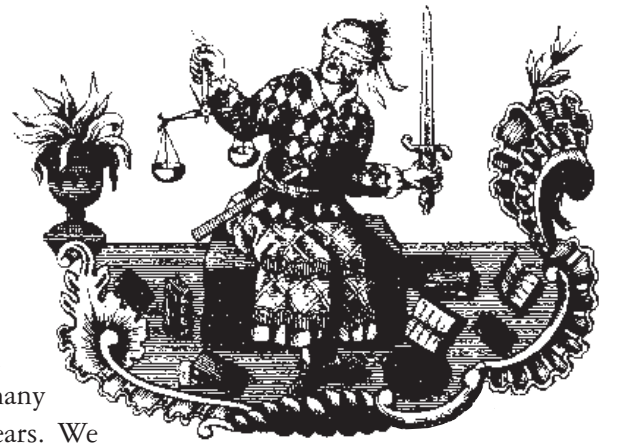
invite you to contact us, visit our website, and subscribe to our mailing list. We issue 12 well-annotated illustrated catalogues per year and occasional catalogues devoted to special topics.

Founded in 1983, The Lawbook Exchange, Ltd. is a longstanding member of the Antiquarian Booksellers' Association of America and the International League of Antiquarian Booksellers.

The Lawbook Exchange, Ltd.

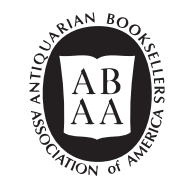

33 Terminal Avenue, Clark, New Jersey 07066 (800) $422-6686$ or (732) 382-1800 - Fax: (732) 382-1887 law@lawbookexchange.com www.lawbookexchange.com

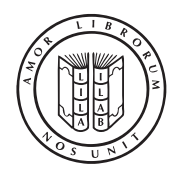

